\title{
THE STUDENTS`VISUAL LITERACY FOR KNOWLEDGE CONSTRUCTION IN THE HISTORY OF LATVIA AND THE WORLD
}

\author{
Liene Ozoliṇa \\ University of Latvia, Latvia
}

\begin{abstract}
The publication aims to present research on the integration of visual literacy in the learning process and its influence on students ' knowledge construction. Mainly in the acquisition of History of Latvia and the World but also related subjects, that is topical in context with ongoing educational reform in Latvia.

Conclusions are based on qualitative data gathered directly from educators of primary and secondary education who developed and approbated assignments for pupils, which includes visual information sources.
\end{abstract}

Keywords: visual literacy, knowledge construction, the History of Latvia, the History of World, educational reform, primary education, secondary education.

\section{Introduction}

The concept of "visual literacy" applies to visual sources of information that have emerged in different periods as a result of the life activities of different people and related to different branches of science - starting with drawings on the walls of the cave, which date back to the prehistoric period, ending with images as elements of multimodal texts created using contemporary technologies. Those technologies make possible the production of visual information sources at large volumes and are rapidly evolving. Thus, visual sources can be offered to audiences measured in millions. Therefore, a situation arises where the daily life of people, including pupils, is saturated with various visual information sources. That affects how people perceive information and the ability of people to analyze it critically. The abovementioned perception and ability are topical both in the science of history to analyze/interpret visual sources of history and in pedagogical science in order to develop critical thinking and construct knowledge. Hence visual literacy is necessary not only to study, develop critical thinking, and to construct knowledge, for example about history, but also to avoid demagogy and propaganda, which is often carried 
out with the help of various modern media which contain essential visual elements.

Considering the topicality of this research - the research work in Latvia, which analyzes the integration of visual literacy in the teaching and learning of history, as well as the activities directed at the development of didactics of history in general, are rare and fragmentary. Often, the integration of visual information sources in the learning process is considered indirectly in the research, or these researches are devoted not to the theory of information source analysis but its application ${ }^{1}$.

In an article and underlying research, the visual literacy is being analyzed as a tool which can be used to develop the ability to interpret images (visual sources of history) to construct knowledge about the history of Latvia and the World. Therefore, the concept of "knowledge construction" also had to be taken into consideration. Concept knowledge construction can be briefly explained as the idea that understanding and remembering information is improved if a person actively tries to process and use the new knowledge in different ways, rather than when one is offered a ready-made informative text intended to be memorized mechanically. Actively using the new knowledge in different ways creates links between the already known and the new information, and it increases the possibility that the new information is going to be included within the pupil's perception of the world. For example, a pupil not only knows the features of a totalitarian regime but is also able to identify them in modern political systems.

The research problem was defined as such: integration of visual literacy for knowledge construction in the process of learning Latvian and world history. The study aimed to explore how visual literacy promotes students knowledge construction about the history of Latvia and the World. The research design that was used to achieve this aim was action research.

In the research literature, no clear concepts were found on how to develop visual literacy by facilitating the construction of knowledge and how to integrate them into the learning process of Latvian and world history. Therefore, the research was designed as an interdisciplinary study, including both the perspectives of history and pedagogy and outlined: 1) the elements of approaches (in the context of Frank Serafini's developed approaches: Art Theory and Critic ${ }^{2}$, Grammar of Visual Design, Media

\footnotetext{
${ }^{1}$ It should be noted that a similar situation in the education environment of Latvia has developed in relation to the didactics of history in general - it lacks a comprehensive, systematic and theoretically grounded approach.

${ }^{2}$ Which is related to Erwin Panofsky's iconological method used by historians to analyze artworks as sources of history.
} 
Literacies (Medienkompetenz) (Serafini 2011)); 2) theoretical examples of assignments (corresponding to "Revised Bloom Taxonomy" (Leslie 2016)) and analysis of assignments which were practically developed and implemented during the study; 3 ) elements of the evaluation criteria that can be developed. The research focus was on exploring the views expressed in theory and confronting them with the situation in the field of visual literacy in the teaching of history in Latvia. So, the research was not limited to theory studies, as it involved collaboration between professionals in the field and practical steps were taken to identify how visual literacy is currently integrated into the history learning process in Latvia and whether and how it is/can be improved.

\section{Methodology}

Methods of data collection used in the research are the content analysis to study the theory of visual literacy in history and pedagogy in the world and Latvia. Secondly, the opinion of the university students - teachers of history and teachers who teach history-related subjects (social sciences, politics, philosophy, cultural studies, literature) - has been studied through the survey.

Discussion to explore the theory and draw conclusions about the visual literacy in the Latvian educational environment, together with practicing history teachers and history teachers in training, as well as other professionals working in history-related institutions (within the University of Latvia, Faculty of History and Philosophy).

Assignment development, with the aim, based on the conclusions of this discussion, to develop assignments and to implement the acquisition of visual literacy integration in the history learning process. Document analysis (different assignments) to obtain data on the effectiveness, positive, and negative aspects of the assignments. Focus group discussion with the participants of the research process to evaluate the possibilities provided by visual literacy in the construction of knowledge.

Action research was chosen because it is directed to cooperation. The cooperation took place between the researcher ${ }^{3}$ and the teachers practitioners (and university students at the same time) - the participants of the study, whose study plan included a course within which the research was implemented and whom themselves work in an educational institution. The cooperation also took place between the participants of the study and

${ }^{3}$ Who pursued some of the lectures in the study course "Vēst5140: Analysis of Historical Sources" and practically works with pupils in primary and secondary education. 
the pupils they taught and with whom approbated the assignments created during the lecture cycle.

The research process lasted about six months and consisted of five stages: 1 ) theory studies and preparation for practice (conducting part of the lecture course during which the research was conducted); 2) work with teachers - university students during the lecture course (lecture, seminars, reflection, assignment development, and implementation); 3) mentoring university students in their work with their pupils; 4) data processing and reporting to formulate and disseminate knowledge.

\section{Results}

\section{Theoretical framework}

The theoretical framework of this research was developed, and its summary is offered further in this article structured as follows: visual literacy as a theoretical problem and research topic; approaches to integrating visual literacy into the teaching process of Latvian and world history; knowledge construction as a concept and its topicality in the Latvian education environment.

\section{Visual literacy as a theoretical problem and research topic}

Topical concept of visual literacy and related semantic fields in the 20th and $21^{\text {st }}$ century have been analyzed in English and German research literature. This research literature offers many designations, which can be attributed to visual literacy ${ }^{4}$. In the Latvian educational environment, this concept (visual literacy) is relatively recent; thus, the discussion about the use of terminology is still ongoing in some ways. In this research, the concept of visual literacy (vizuālā pratība) was applied due to it being used in the educational environment of Latvia (Gorbāns 2010). It can be briefly defined as "ability to interpret images and create new images to communicate ideas and concepts" (Stokes 2002, 10). Also, it must be added that the alternative use of this concept is being used in the educational environment of Latvia. The concept of visual literacy (vizuālizpratne) has been adopted in the Latvian language as "a complex

${ }^{4}$ For example, "Bildliteralität", "visual competence", "visuelle Kompetenz", "image competence", "Bildkompetenz", "visual education", "visuelle Bildung", "visual learning", "visuelles Lernen". These designations can be attributed to close standing semantic fields and often are used as synonyms (Hug 2012). More detailed explanation and analysis of concepts can be found in the Masters' thesis "The Students' Visual Literacy for Knowledge Construction in the History of Latvia and the World". (Ozolina 2018, 10-13). 
compound of sub-competencies for the reception and production of images, as well as reflection of these processes." (Friče 2019, 142). This concept is used because visual literacy in conjunction with concepts used in Latvian to describe literacy (such as "izpratība," "rakstītpratība," "pratība") "is too narrow a concept, and it is necessary to define it as a visual competence to cover all attributed to it. [..] as a competence that encompasses knowledge, skills, and attitudes and is more freely applicable to different fields." (Avotiņa 2019, 37)5.

Integrating visual literacy in the learning process evaluation criteria and guidelines should be developed to identify whether a person can work with visual information sources qualitatively. Criteria must be relevant to the education of the 21st century, so there should be defined achievable results. The achievable results after which it is possible to determine the level of visual literacy should not be simplified. For example, the capability of recognizing the works of specific artists is not an absolute indicator of visual literacy but only refers to a specific element of it.

Developing visual literacy requires to take in to account several elements. Firstly, the development of the ability to recognize, classify and perceive the direct meaning and essence of perceived visual information. Secondly, it requires developing the ability to work with and interpret visual information sources qualitatively. For example, analyzing a visual information source in the context with an era in which it was created. Thirdly, use the information obtained by linking it with either emotions or cognitive activities with the purpose of understanding previously acquired information, confronting with other sources of information, and creating something new. Fourth, it is necessary to develop the ability to share with the newly created unit, to form and defend their reasoned opinion.

Criteria that describe the acquisition of visual literacy can be defined as such: firstly, uses digital technologies to find and process visual information sources, as well as can identify the types and volumes of sources that will be needed to achieve the goal. Secondly, can interpret, analyze, and evaluate visual materials, as well as the sources from which these materials were derived and authors' motivation. Understands how and why a visual source of information has been created, as well as what it implies. Knows and can apply the strategies necessary for both internal and external source criticism. Third, can use visual sources of information to communicate, as well as creates new sources of visual information. (Ozolinga 2018, 14-15, 17-18)

${ }^{5}$ This use of concept was not included into the theoretical framework of research due to it being published after the research was already finished. 


\section{Approaches to integrating visual literacy into the teaching process of Latvian and world history}

The English and German research literature connected with the analysis of visual information sources contains a wide range of research. However, the problem of integrating theoretical research into pedagogical activity and conducting empirical research still exists today. In 2015, it was pointed out that research on visual information sources in teaching methodology is rare and that researchers and professionals in the field often have to adapt their methodological solutions from similar disciplines (Hecke 2015, 179).

The problem of no consensus on the use of the concept and possibilities of integrating it in education can be linked with concepts "visual literacy" contradictory nature. On the one hand, it is a multidimensional concept which is topical in many fields of knowledge and contexts. For example, "aesthetics, anatomy of the eye, body language, cognitive psychology, communication theory, cultural anthropology, instructional technology, mental imagery, neurophysiology, perceptual development, psycholinguistics, semantics, and visual perception." (Michelson 2017). So the desire to make visual information source analysis interdisciplinary is logical in order to avoid misunderstandings, especially in the primary and secondary school. On the other hand, in this research, the process of integrating visual information sources, specifically in the field of history teaching and learning, was essential. In order to understand how it is possible to integrate visual information sources in history teaching and learning process, it is necessary to find points of contact between, firstly, approaches and methods that are topical in the field of academic history, secondly, to what extent and how these approaches and methods can be integrated into general education.

Essential approaches to research are analyzed as complementary: Grammar of Visual Design, Media Literacies; Medienenkompetenz, Art Theory, and Critics. According to Frank Serafini, who defined these approaches: "provide teachers with diverse lenses through which to focus students' attention to visual aspects of the multimodal texts they encounter. “(Serafini 2011, 343).

The grammar of Visual Design - the author proposes to structure this approach around three essential elements: composition, perspective, and visual symbols. The first two elements of this approach are in line with the first level of the iconological method ${ }^{6}$ or pre-geographical description.

\footnotetext{
${ }^{6}$ The method developed by Ervin Panofsky and other so-called Warburg`s school representatives, they insisted that one does not have to put up with a formal approach to the analysis of a work of art (by analyzing only style, composition, color), but the analytical practice must be developed and artwork used as a source of history.
} 
Using this approach and its analogy with the iconological method, one can master basic concepts, develop the skills to verbally express the visible elements - objects, events, artistic style features. It makes possible further analysis of the source of visual information, which, in the case of history, is related to the exploration of the context of the creation of the artwork.

Media Literacies / Medienenkompetenz - this approach corresponds to the second level of the iconological method or iconographic analysis. Applying it, it develops the ability to understand, question, and critically evaluate different types of sources in different contexts. Understand the ways, techniques, and goals with which the message contained in the source is created. From the perspective of the iconological method, artistic motives, or combinations of them, should be linked to different themes, concepts, identifying specific scenes and allegories. Attention should be paid to how the particular theme, the concept was depicted in the respective historical period - it is necessary to expand the knowledge of the specifics of historical periods and traditions of representation in this historical period. So it also develops the ability to choose the source of information according to the situation or the goal.

Art Theory and Critics - this approach is modeled based on the iconological method, offering educators to use the structure of it as a framework to develop pupils' understanding of the visual elements of multimodal texts. In the context of the previous approaches, the first two levels of the iconological method were described. The third level of the iconological method aims to make possible the interpretation of the meaning and content of the work of art. It is done by using information obtained during the first two levels of analysis. Visual information source in history science is seen as an expression of the attitude of the people of the historical era towards the world. Therefore, at this level, it is possible to determine the historical context of the artwork, its message, and underlying values. In order to determine previously mentioned, extensive knowledge of history is needed.

It should be noted that in the research literature the direct adoption of the iconological method at primary and secondary school level is not evaluated positively because this method is too advanced and specific to the level of general education (Schreiber 2004, 60). However, if the structure and elements of this method are qualitatively integrated into the learning process, they can contribute to good results.

\section{Knowledge construction as a concept and its topicality in Latvian education environment}

"Knowledge construction" is a contemporary concept in the modern world and Latvian education environment, where the essence is that the pupil uses facts, information received and builds knowledge. 
One of the fundamental insights underlying the concept is that human thinking processes work so that new information is associated with already known information as well as personal experience. The process of capturing and processing new information can give a new perspective on person's existing knowledge, supplementing the new information with details, and building a relationship (links) between the already known and newly acquired information. The function of these activities is to help a person reformulate the new knowledge or to restructure the existing knowledge, reaching a deeper level of understanding. Understanding the new information and the ability to remember it is enhanced if a person actively participates in the knowledge construction process and tries to process and use the new knowledge in different ways. When a person works with new information, constructs knowledge, creates new and changes existing associations that ensure that the human knowledge structure changes and improves ${ }^{7}$. Above mentioned links between the already known and the newly discovered information ensure that the new information is included within the persons ' perception of the world ${ }^{8}$. With the qualitative formation of such links, a more complex and better integrated cognitive structure is created in the human mind, which facilitates the process of remembering, the ability to recall the information (After King 1994, 339).

The knowledge construction process can be characterized by several elements and activities that are also typical of Bloom's taxonomy (Bloom, et al., 1956) and Revised Bloom's taxonomy (Anderson, Krathwohl et al. 2001). ${ }^{9}$

When examining the relationship between visual literacy and the construction of knowledge, two aspects should be considered. Firstly, from the perspective of the historical development of humanity - is to be taken into account that there has been a visual culture at all stages and regions of civilization development, and it has always been essential in matters related to the process of human communication and knowledge acquisition (Hug, 2012). Also, the fact that visual communication forms existed long before the emergence of written communication.

Secondly, from the perspective of human development - information that children derive from visual information sources is fundamental to their development and learning process. Because "children learn to perceive and interpret, that is to "read" body language and other visual signs before they

\footnotetext{
${ }^{7}$ In contrast to a situation in which one has to remember unknown information offered as a ready-made informative text which has to be mechanically remembered.

${ }^{8}$ For example, a pupil not only knows the features of a totalitarian regime but is also able to identify them in modern political systems.

${ }^{9}$ A comparison of taxonomies with examples of assignments that integrate visual literacy can be found in the Master's thesis underlying this article (Ozolina 2018, 27-29).
} 
begin to perceive and interpret, to "read" the words they hear. In fact, for the seeing child, it is primarily the successful "reading" of visual signs that makes possible the "reading" of heard verbal signs. For him, this primacy of visual information in human development made it a critical feature in the formation of language and, subsequently, knowledge." (Michelson 2017, 95).

\section{Data analysis and evaluation}

Lecture cycle was carried out to obtain data from study courses that took place at the University of Latvia - "SDSKR003: Master's Practice in Research" and "Vēst5140: Analysis of Historical Sources". Participants of this lecture cycle had to: a) fill out a survey "Visual sources of information in history and related subjects," which aimed to obtain qualitative (rather than quantitative) data to explore teachers' experiences in integrating visual literacy into the learning process; b) to develop, implement and reflect on assignments for primary and secondary education pupils which were aimed to develop visual literacy and improve knowledge construction. Partaker of the study were students studying to obtain history teacher's qualification and had to attend above mentioned lecture cycle, a person who works at the museum and was interested in attending lecture cycle and teachers of subjects which are related to history.

\section{Survey}

Analyzing data gained by the survey, it was concluded that $88,9 \%$ of respondents use visual information sources at their pedagogical practice. Motivation tendencies of doing so can be defined as a) practical reasons, e.g., visual sources are used in textbooks and methodical materials used by the teacher; b) subject specificity, e.g., visual art, cultural science, art history; c) peculiarities of pupil perception, e.g., nowadays, visual information sources play an essential role in the daily life of children and young people. Therefore, the information should be provided in a more easily understandable way; d) development of pupils' critical thinking, e.g., encourages the pupils to think, interpret different elements of the image, their meaning, and relation to the time of the creation of the source and its purpose.

When asked to identify knowledge and skills needed for dealing with visual information sources respondents identified such needed knowledge: about time, the area of what the visual source provides information; about the cultural era represented by the source; knowledge of source creation techniques and technologies; preliminary knowledge in the field of visual research (this should instead be attributed to skills); basic knowledge of means of art expression and their use. Skills defined as necessary for 
analyzing visual sources was: the ability to select the necessary information; ability to see the details and the overall picture; ability to analyze, select and group information; ability to see, observe, analyze, conclude.

More detailed responses about what knowledge is needed to analyze visual information sources have been provided by respondents whose activities have been linked to visual sources of information outside their pedagogical process. In general, respondents have the understanding that visual information sources should be viewed in context with the place and time of creation, and that there is a need for specific knowledge to work with visual information sources. About the necessary skills - the impression is that most respondents have no notion of the specific skills needed to work with visual information sources because respondents mostly indicated the skills needed to analyze different sources of information in general.

Respondents were asked to provide their examples of assignments that included visual information sources. These assignments were of different degrees of complexity and meant for people of different ages. Assignments reflected the perception of respondents on how to use visual information sources in the pedagogical process. It was observed that this understanding is related to respondents' education and experience of working with visual information sources outside of school. Not all respondents were able to define the purpose of their proposed assignment adequately and to clearly define what knowledge and skills are needed or developed in the process of performing the assignment.

Respondents had to analyze four assignments that included visual information sources. One of the criteria that had to be analyzed was to evaluate the potential of the assignment in constructing pupils' knowledge and its potential to develop skills to work with visual information sources. The study analyzed two assignments and respondents' views on them - respondents rated one of these assignments as the most relevant to the previously defined criterion, but other as the least appropriate. In the assignment that respondents rated as meeting the criteria, respondents saw the need to use both knowledge and skills. Respondents did not define the need to apply any skills in an assignment that was assessed as irrelevant to criteria.

Thus, it can be concluded that in assignments aimed at developing visual literacy and promoting knowledge construction, it is necessary to include both the need to use the knowledge and the opportunity to develop skills. As well it is crucial to design assignments in which visual sources are included meaningfully not formally. It seems logical, but when analyzing the exams in the History of Latvia that were offered until 2018, it could be established that the percentage of visual information sources to be included is low, as well as the fact that these assignments (such as those offered 
to respondents in the survey which were included in the 2019 and 2011 exams in Latvian History for $9^{\text {th }}$ grade) do not always offer adequate use of skills in the analysis of visual information sources. Similar conclusions can be attributed to exams (regarding $9^{\text {th }}$ grade) of other years $-2015,2016$, 2017. Mentioned exams are analyzed in the master's thesis “The Students' Visual Literacy for Knowledge Construction in the History of Latvia and the World" (Ozolina 2018, 39-40) on which this publication is based.

However, the situation has improved in the 2018 (National Centre for Education 2018, https://visc.gov.lv/vispizglitiba/eksameni/dokumenti/ uzdevumi/2018/9klase/9kl_vesture_lv.pdf) and 2019 exams (National Centre for Education 2019, https://visc.gov.lv/vispizglitiba/eksameni/ dokumenti/uzdevumi/2019/9klase/9kl_vesture.pdf). In the 2018 exam, the visual source of information had to be confronted with the written ones (3., 6., 7. assignments in Part 2 of the exam), in 2019 (9. Assignment in Part 2 of the exam) the visual information sources (political posters) had to be linked to the historical reality of the time of their creation. Thus, those assignments can be rated as meaningful and demanding usage of more advanced skills in analyzing visual sources.

\section{Development, implementation and reflection on assignments}

In addition to the survey, assignments developed, and implemented during the lecture cycle meant to integrate visual literacy in the learning process to facilitate knowledge construction, were also analyzed. Each participant had to develop two assignments, but their analysis includes one of the assignments offered by each participant, as they were similar in the approach and showed a similar understanding of the respondent's visual literacy and knowledge construction elements. The developed, approbated assignments, their descriptions, data summaries, and essays provided by the participants of the research were analyzed. The results were categorized: knowledge and skills that each exercise helps to develop, and conclusions.

The following are two examples of assignment analysis: one assignment meant for elementary and one for secondary school. The assignment for elementary school - pupils were given the assignment of analyzing a propaganda poster of the Vichy regime and answering ten questions about the poster. The knowledge that it helps to construct can be defined as such: French policy and society during the Vichy regime; the concepts of propaganda, motto, occupation, cultural values; social roles attributed to genders during the Vichy regime.

Skills what this assignment develop was defined as such: reasonably judge semi-familiar information that hides the instructions that can be used to perform an assignment; using visual symbols to determine which country is covered by the proposed poster; determine what type of propaganda 
(national-socialist / fascist; communist; democratic) is visible in the poster and what visual signs show it; to conclude (given three options) the correct translation of the motto offered in French; to identify the historical personality seen in the poster, knowing which country and in what period this poster has been created; to define the concept of the ideal society offered by the Vichy regime based on a diverse depiction of different social groups of men and women; to make conclusions about the cultural values of the regime, using a visual source of information. It can be concluded that this assignment develops the child's logical reasoning about semifamiliar information. Also, the questions (regarding visual source) should be organized in a particular order so that the pupil can step by step build their knowledge - starting with the lightest questions (also in the test format) and ending with the most difficult - judging what regime the poster reproduces.

The assignment for secondary school was developed by museum pedagogue, which determined the specificity of the assignment in question and the ability to implement it. The pupil should choose one particular cultural field that was relevant to the turn of the 19 th and $20^{\text {th }}$ centuries and find information about this area in the period considered. For example, press, photographs, memories, documents (if available), works of art can be used as sources. Besides, literature that can be obtained from a library or websites should be used. Based on the information obtained, the pupil has to draw a cartoon (analogous or digital) about an event, a situation that has been topical in a particular time and cultural field. The assignment supports the knowledge construction of the: concept "cartoon"; visual culture of the particular period; current events and personalities in a given period. Skills what this assignment develop was defined as such: identify what sources of information are available about a particular area, personality, event; to work with a visual source of information rather than perceive it as a static illustration of the era; to apply Erwin Panofsky's iconological analysis, at least its first two levels; to get information both from the source and create a new source of visual information.

It can be concluded that the assignment has considerable potential to develop the ability to work with visual information sources - one must be able to perceive the particular period of history and make the cartoon so that it can be perceived in the social and historical context of the appropriate time.

When discussing an assignment ${ }^{10}$, the negative aspects of it were defined - the assignment is too time-consuming and therefore, impossible

${ }^{10}$ It should be taken into account that this assignment was not implemented. But the author of the assignment discussed it with his colleagues in the museum, as well as with the participants of the lecture cycle and the author of this study. 
in the museum environment. Execution of the assignment would require the preparation of a particular project, as it is not included in the museum's offer. Besides, experience shows that teachers do not usually have the time to invest many resources in preparing for a museum visit. The pupil may not have enough understanding of what the cartoon is. It is doubtful whether the pupils would understand how to transfer the information about the period to the cartoon form. The suggestions were made in order to make assignment possible, firstly, to develop an assignment as a project where one part is done at school, but the other part at the museum. However, the author of the assignment, based on experience, stated that it would not be possible. Secondly, to change an assignment from making a cartoon to making a comic strip - possibly a more understandable option for pupils.

It can be concluded, analyzing all the information obtained during the study, that visual information sources can be integrated into the learning process in different ways, in order to develop knowledge construction. Visual sources of information can be used as introductory material for a topic. In this case, the assignments should be designed to enable students to retrieve and classify the knowledge relevant to the new topic from the visual sources using the skills required to analyze those sources. Visual sources of information can also be used to encourage pupils' emotional attachment to learning content that can improve the learning process. Visual information sources can also be used as a guide to the learning process, which can help in the construction of new knowledge and the development of skills using existing knowledge and skills. In this case, the assignments should be designed to acquire new knowledge and develop skills through existing knowledge and skills and logical actions and conclusions. Visual sources of information can also be used to create the content depth of a known topic. In this case, the assignments should offer students the opportunity to use the knowledge they have about a topic to find and implement opportunities to explore the topic more in-depth, possibly using atypical methods. In visual information sources, time structures are not primary, unlike verbal sources of information, so visual information sources can also be used to stimulate the analysis of problematic issues in several time dimensions simultaneously - in the past, present and future. It can develop the ability to look at specific situations and issues more broadly, taking into account the experience of people who have lived in different periods and locations.

\section{Conclusions}

The essential outcomes were several, firstly, examining the theoretical material in which concepts of visual literacy and knowledge construction have been analyzed from the perspective of history and pedagogy, led to 
a conclusion that the concepts visual literacy and knowledge construction are not clearly defined as well as the principles of integration of visual literacy and knowledge construction in the history study process. Also, the intention of research to tightly integrate pedagogy and history from various aspects is atypical in the Latvian educational environment at the academic level. Since at this level, research in didactics of history is fragmented and underdeveloped. Due to this, the elements of approaches, evaluation criteria, and guidelines were outlined in the research (see Sect. 1.1., 1.2.).

Secondly, the unified understanding of the integration of visual literacy in the learning process among teachers of the history and related subjects (similar to the research literature) was not detected. This conclusion was made both by carrying out the content analysis of different sources of information and by offering respondents who work in educational institutions and whose work is related to history, to fill out a survey on visual literacy and knowledge construction. The qualitative analysis of the obtained data led to the conclusion that visual information sources are integrated into the learning process and that respondents were partly able to define the knowledge and skills necessary to analyze visual information sources.

Thirdly, as a result of research, during the master's practice at the University of Latvia Faculty of History and Philosophy, the lecture cycle was implemented. During the lecture cycle actions of participants were moderated. The objective was to develop participants (as practicing history educators) ability to use visual information sources in the learning process. Another objective was to construct participants understanding of concepts visual literacy and knowledge construction.

Fourth, evaluating the experience and data gained during the study it can be concluded (see Sect. Chap.2) that the visual sources of information should be used in different ways and different parts of the study process. Visual literacy can be integrated into all parts of the learning process a) introduction of the content; b) creating an emotional attachment to the given content; c) using existing knowledge and skills to gain new knowledge and skills; d) to develop a depth of content; e) to analyze one problem in different time dimensions. Also, visual literacy integrated into different parts of the learning process can be used to encourage knowledge construction.

Practical use of the research can be defined as such - the outlined elements of approaches, evaluation criteria, guidelines, developed and analyzed assignments regarding visual literacy and knowledge construction can be directly implemented into the history learning process. As for the scientific novelty of the research - it focuses on a specific field of 
studies that encompasses two branches of science and two concepts of "visual literacy" and "knowledge construction" used in different contexts. There is no consensus in this field of research in the broader context, but in the Latvian educational environment at an academic level, it is related to the area of neglected didactics of history and thus is fragmented and understudied.

However, it should be noted that the following factors influenced the implementation of the research: a) the study was carried out during previously mentioned lecture cycle at the University of Latvia, which determined both the orientation of the research topic, the circle of partakers, respondents and methods used during research. b) the study involved people working in educational institutions in Latvia who work with primary and secondary education students. It determined the aspects of the study related to the age peculiarities of the students, the topics covered in history lessons, as well as the resources available and methods chosen to implement different ideas.

Further research perspectives could be defined as follow: a) possibilities of integrating visual information sources in the study process of history to foster the construction of pupils' knowledge, could be further explored involving a more comprehensive range of participants; b) the lecture cycle during which the study was carried out could be re-implemented to confront the newly obtained data and its analysis with those obtained in this study; c) implemented and analyzed assignments were developed corresponding to "Revised Bloom Taxonomy" (Leslie 2016). However, in context with ongoing educational reform in Latvia (National Centre for Education http://visc.gov.lv/visc/projekti/esf_831.shtml), it would be beneficial to reconsider developed assignments using SOLO taxonomy which "describes the growth in complexity of performance in many learning assignments, from the earliest engagement in the assignment to expertise. Learning grows along at least two dimensions: (a) the level of abstraction, or mode, of the contents learned (five such modes are recognisable from infancy to adulthood); and (b) the cycle of increasing complexity that learning undergoes within any given mode [..] to state the desired level of performance in many important curriculum topics in a way that can be used (a) for criterion-referenced assessment in particular subjects, and (b) for discussing comparable levels of attainment across different subjects and different schools." (Biggs, Collis 1989, 151). 


\section{References}

Anderson, L. W. (Eds.), Krathwohl, D. R. (Eds.), Airasian, P. W., Cruikshank, K. A., Mayer, R. E., Pintrich, P. R., Raths, J., Wittrock, M. C. (2001). A taxonomy for learning, teaching, and assessing: a revision of Bloom's taxonomy of educational objectives. New York: Longman.

Avotina, A. (2019). Vizuālizpratne kā 21. gadsimta kompetence (Avotina, A. (2019). Visual literacy as a $21^{\text {st }}$ century competence). No: Avotina, A., Stikāne, I. (red.) Vizuālizpratne kā 21. gadsimta kompetence. (Avotina, A., Stikane, I. (Eds.) (2019). Visual literacy as a $21^{\text {st }}$ century competence). Rìga: Latvijas Universitāte (Riga: University of Latvia).

Biggs, J., \& Collis, K. (1989). Towards a Model of School-based Curriculum Development and Assessment Using the SOLO Taxonomy. Australian Journal of Education, 33(2), 151-163. https://doi.org/10.1177/168781408903300205 (20.06.2019.).

Bloom, B. S., Engelhart, M. D., Furst, E J., Hill, W. H., Krathwohl, D. R. (1956). Taxonomy of educational objectives: The Classification of Educational Goals. London: Longmans, Green \& Co. Retrieved from: https://www.uky.edu/ rsand1/china2018/ texts/Bloom\%20et\%20al\%20-Taxonomy\%20of\%20Educational\%200bjectives.pdf (20.06.2019.).

Friče., M. (2019). Terminu vārdnīca // Vizuālizpratne. (Fritzsche, M. (2019). Glossary// Visual literacy.) No: Avotina, A., Stikāne, I. (red.) Vizuālizpratne kā 21. gadsimta kompetence. (Avotina, A., Stikane, I. (Eds.) (2019). Visual understanding as a $21^{\text {st }}$ century competence). Rīga: Latvijas Universitāte (Riga: University of Latvia).

Gorbāns, I. (2010). (Gorbans I. (2010) MOODLE e-mācību ieviešanas profesionālās izglītības iestādēs koncepcija. (Implementing MOODLE e-learning in vocational education institutions.) Pieejams: http://profizgl.lu.lv/mod/book/view.php?id = 16456\&chapterid $=3173$ (20.06.2019.).

Hecke, C. (2015). Visual literacy and Foreign Language Learning. In: Bigelow, M., Ennser-Kananen, J. (eds.) The Routledge Handbook of Educational Linguistics. NewYork: Routledge.

Hug, T. (2012). Media competence and visual literacy - towards considerations beyond literacies. // In: Periodica Polytechnica. Vol. 20., No. 2. Retrieved from: https://pp.bme. hu/so/article/view/1574 (20.06.2019.).

King, A. (1994). Guiding Knowledge Construction in the Classroom: Effects of Teaching Children How to Question and How to Explain. In: American Educational Research Journal. Vol. 31, No. 2, pp. 338-368 Retrieved from: http://journals.sagepub.com/doi/ pdf/10.3102/00028312031002338 (08.05.2018.).

Leslie, O. W. (2016). Anderson and Krathwohl - Bloom's Taxonomy Revised: Understanding the New Version of Bloom's Taxonomy. Retrieved from: https:// thesecondprinciple.com/teaching-essentials/beyond-bloom-cognitivetaxonomy-revised/ (22.06.2019.).

Michelson, A. (2017). A short history of visual literacy: the first five decades. In: Information Literacy in UK and US Art Libraries, Volume 42, Issue 2, 95-98.

National Centre for Education. (2018) Examination in the history of Latvia calss 9. Retrieved from: https://visc.gov.lv/vispizglitiba/eksameni/dokumenti/uzdevumi/ 2018/9klase/9kl_vesture_lv.pdf (20.06.2019.). 
National Centre for Education. (2019) Examination in the history of Latvia calss 9. Retrieved from: https://visc.gov.lv/vispizglitiba/eksameni/dokumenti/uzdevumi/2019/ 9klase/9kl_vesture.pdf (20.06.2019.).

National Centre for Education. ESF project No. 8.3.1.1/16/1/002 "Competency based curriculum" or Skola2030 ("Kompetenču pieeja mācību saturā" jeb Skola2030) Retrieved from: http://visc.gov.lv/visc/projekti/esf_831.shtml (24.06.2019.).

Ozolina, L. The Students` Visual Literacy for Knowledge Construction in the History of Latvia and the World. Riga: University of Latvia, 2018, 10-13. Retrieved form: https:// dspace.lu.lv/dspace/handle/7/38491 (20.06.2019.).

Schreiber, W. (2004). Der Historiker und die Bilder: Grundlegungen für den Geschichtsunterricht. (The historian and the pictures: foundations for history lessons.) In: Schreiber, Waltraud (Hrsg): Bilder aus der Vergangenheit - Bilder der Vergangenheit? (Bilder aus der Vergangenheit - Bilder der Vergangenheit?) Neuried: Ars una.

Serafini, F. (2011). Expanding Perspectives for Comprehending Visual Images in Multimodal Texts. Journal of Adolescent \& Adult Literacy, Vol. 54, No. 5, P. 342-350.

Stokes, S. (2002). Visual Literacy in Teaching and Learning: A Literature Perspective. // In: Electronic Journal for the Integration of Technology in Education. Vol. 1., No. 1. (pp. 10-19) Retrieved from: https://wcpss.pbworks.com/f/Visual + Literacy.pdf (20.06.2019.).

\section{Information about the author}

Liene Ozolina, Mg. hist., Mg. paed. Research interests include history didactics, visual literacy, and knowledge construction. The author obtained the master's degree in history (2015) and the professional master's degree in pedagogy (2018) from the University of Latvia. Currently teacher of History of Latvia and the World to primary and secondary level students. Also, a member of the board of History and Social sciences Teachers' Association of Latvia. 